W stużbie tradycji i odnowy liturgicznej. 50 lat Instytutu Liturgicznego w Krakowie (1968-2018), red. P. Nowakowski, J. Mieczkowski, Kraków 2019, s. 47-54.

ISBN 978-83-7438-849-8 (wersja drukowana), ISBN 978-83-7438-850-4 (wersja online) DOI:http://dx.doi.org/10.15633/9788374388504.05

Przemysław Nowakowski CM

Unimersytet Papieski Jana Pawea II w Krakowie, Polska

ORCID: 0000-0002-8402-3626

\title{
Międzynarodowe Sympozja Liturgiczne "Ad Fontes Liturgicos". Krótka historia nowej inicjatywy Instytutu Liturgicznego w Krakowie
}

Nową inicjatywą Instytutu Liturgicznego są międzynarodowe sympozja liturgiczne pod hasłem „Ad Fontes Liturgicos”. Inicjatywa tych corocznych spotkań liturgistów zrodziła się w 2010 roku we współpracy jednostek naukowo-badawczych trzech sąsiednich krajów: Polski, Ukrainy i Słowacji. Obok Instytutu Liturgicznego UPJPII sympozja są organizowane przez Ukraiński Uniwersytet Katolicki we Lwowie (Katedra Nauk Liturgicznych) i Greckokatolicki Wydział Teologiczny Uniwersytetu Preszowskiego w Preszowie. W 2015 roku do tego grona współorganizatorów sympozjum dołączył Instytut Teologiczny św. Atanazego w Nyíregyházie z Węgier. Sympozja "Ad Fontes Liturgicos” odbywają się regularnie co roku pod koniec października, a ich gospodarzami są na przemian uczelnie z wymienionych wyżej krajów Europy Środkowo-Wschodniej. Po sympozjach staraniem poszczególnych ośrodków - gospodarzy - publikowane są teksty wygłoszonych referatów w tomach, które składają się na swoistą międzynarodową serię wydawniczą Ad Fontes Liturgicos. Dotychczas wyszło 
drukiem sześć tomów serii (w druku jest tom siódmy, a w przygotowaniu - ósmy).

Ideą sympozjów „Ad Fontes Liturgicos” [dalej: AFL] jest umożliwienie spotkania się i dyskusji specjalistów z różnych krajów, należących do różnych tradycji liturgicznych (łacińskiej i bizantyjskiej), zajmujących się badaniem źródeł liturgii w celu zaprezentowania wyników swoich poszukiwań i wymiany doświadczeń badawczych i dydaktycznych.

Pierwsze sympozjum odbyło się w Krakowie 21 października 2010 roku, a jego temat przewodni brzmiał Powrót do źródet. Metodologia i teologia w badaniach źródet liturgicznych. Organizacją konferencji ze strony Instytutu Liturgicznego kierował ks. dr hab. Przemysław Nowakowski. Wygłoszono dziewięć referatów (trzech prelegentów z Polski, sześciu z zagranicy) $)^{1}$. Prelegenci ukazali problemy metodologiczne badania ksiąg i rękopisów liturgicznych należących do tradycji łacińskiej i bizantyjskiej. Zwrócono uwagę na to, że teksty liturgiczne powinny być dzisiaj nie tylko źródłem poznania dawnej liturgii, ale inspiracją dla rozwoju myśli teologicznej, tak jak było w historii Kościoła, zwłaszcza w pierwszych wiekach chrześcijaństwa.

Pierwszymi kontynuatorami inicjatywy cyklu sympozjów byli koledzy liturgiści z Ukrainy (dr Taras Shmanko, o. dr Wasyl Rudejko). Do organizacji drugiego sympozjum (AFL2) we Lwowie włączyły się dwie tamtejsze jednostki naukowo-badawcze: Ukraińskie Centrum Liturgiczne, związane z greckokatolickim wydawnictwem Swiczado, i Ukraińskie Naukowe Towarzystwo Teologiczne. Temat sympozjum: Powrót do źródet. Badania źródeł liturgii pontyfikalnej pozwolił na przedstawienie kilku interesujących zabytków liturgicznych (rękopisów i starodruków) - wschodnich (bizantyjskich, serbskich, staroruskich) archieratikonów i zachodnich pontyfikałów. W sympozjum lwowskim referaty wygłosiło trzech przedstawicieli Instytutu Liturgicznego z Krakowa, a obok liturgistów słowackich i ukraińskich wystąpiła także doktor z Uniwersytetu Wiedeńskiego (s. Vassa Larin). Akta sympozjum zostały opublikowane w periodyku Ukraińskiego Towarzystwa Teologicznego „Bohoslovia”².

1 Por. Powrót do źródet. Metodologia i teologia w badaniach źródeł liturgicznych, red. J. Mieczkowski, P. Nowakowski CM, Kraków 2012 (Ad Fontes Liturgicos, 1).

2 Por. „Bohoslovia” 71 (2010/2011), s. 5-106. 
W 2012 roku sympozjum AFL gościło po raz pierwszy na Słowacji, na Greckokatolickim Wydziale Teologicznym Uniwersytetu Preszowskiego w Preszowie, głównie dzięki zaangażowaniu dwóch wykładowców tego wydziału - profesorów Wojciecha Bohača i Marcela Mojzeša. W ten sposób wyłoniła się ostatecznie grupa głównych organizatorów sympozjów z trzech sąsiednich krajów: Polski, Ukrainy i Słowacji. Sympozjum AFL3 realizowało temat Ruch liturgiczny jako skutek powrotu do źródeł liturgicznych, podejmując $\mathrm{w}$ ten sposób historyczną refleksję nad samym procesem powrotu do źródeł w najnowszych dziejach Kościoła³. Polskę reprezentowało czterech liturgistów: trzech z Instytutu krakowskiego i ks. prof. Erwin Mateja z Uniwersytetu Opolskiego. W Preszowie wspólnie podjęto decyzję kontynuowania sympozjów „Ad Fontes Liturgicos” w kolejnych latach w poszczególnych krajach - organizatorach projektu.

Sympozjum wróciło więc znowu do Krakowa w roku 2013 (23-24 października), roku pięćdziesięciolecia konstytucji o liturgii, uchwalonej 4 grudnia 1963 roku. Ta rocznica zdeterminowała temat czwartego sympozjum AFL, który brzmiał Reformy liturgii a powrót do źródeł (Riforme della liturgia e il ritorno alle fonti). W swojej czwartej edycji sympozjum AFL nabrało rozmachu i zgromadziło aż 25 naukowców z siedmiu krajów Europy. Obok przedstawicieli trzech organizatorów sympozjum pojawili się także liturgiści z Węgier (trzech), Słowenii (dwóch), Włoch (dwóch) i Belgii (jeden). Szukano odpowiedzi na pytanie, czy i w jakim stopniu historyczne reformy liturgii różnych obrządków były powrotem do źródeł. Stwierdzono, że proces powrotu do źródeł (fr. ressourcement) w doświadczeniu różnych Kościołów chrześcijańskich trwa nadal, powinien być jednak prowadzony równolegle z szukaniem przez liturgię i liturgistów sposobu dotarcia do wrażliwości współczesnego człowieka (wł. aggiornamento). Z uwagi na obecność licznych prelegentów z Europy Zachodniej drugim językiem sympozjum był włoski, popularny wśród liturgistów, którzy często studiują w papieskich uczelniach Rzymu. Podczas sympozjum w Muzeum Historyczno-Misyjnym Zgromadzenia Księży Misjonarzy w domu zgro-

3 Por. Liturgické hnutie ako dôsledok návratu k liturgickým prameňom, red. V. Bohač, M. Mojzeš, Prešov 2012 (Ad Fontes Liturgicos, 3).

4 Por. P. Nowakowski CM, Wprowadzenie, w: Reformy liturgii a powrót do źródet, red. J. Mieczkowski, P. Nowakowski CM, Kraków 2014, s. 5-8 (Ad Fontes Liturgicos, 4). 
madzenia, w którego murach odbywały się obrady, została otwarta okolicznościowa wystawa pod tytułem „Liturgia wczoraj i dziś” (organizator ks. Wacław Umiński, dyrektor muzeum). Cała konferencja była transmitowana na żywo przez krakowskie radio internetowe Nowohuckie.pl i została zarejestrowana na płycie CD. Obszerna publikacja pokonferencyjna AFL4 liczy prawie 400 stron$^{5}$.

Sympozjum AFL5 na temat Komentarze liturgiczne jako źródło nauki o liturgii odbyło się 23 i 24 października 2014 roku we Lwowie. Tym razem ze strony ukraińskiej głównym organizatorem stał się Ukraiński Katolicki Uniwersytet (UKU). Przedstawiono kilka komentarzy liturgii zarówno tradycji łacińskiej, jak i bizantyjskiej, wykazując ich wielkie znaczenie dla poznania samej liturgii dawnych wieków i jej teologicznych interpretacji. Obecni byli przedstawiciele tradycyjnych już współorganizatorów sympozjum „Ad Fontes Liturgicos”. Polski wkład w to sympozjum to cztery referaty, wśród których zasługuje na podkreślenie tekst seniora krakowskich liturgistów ks. prof. Stefana Koperka pod tytułem Rok liturgiczny Prospera Guérangera komentarzem wprowadzajacym w liturgię $i \dot{z y c i e ~ c h r z e s ́ c i j a n ́ s k i e ~}{ }^{6}$ oraz wystąpienie pani dr Alicji Nowak z Uniwersytetu Jagiellońskiego w Krakowie o wprowadzeniach do ksiąg liturgicznych metropolii kijowskiej w XVI i XVII wieku7. Ukraińska publikacja aktów sympozjum AFL5 była już osobną książką ${ }^{8}$ przygotowaną przez Wydawnictwo Ukraińskiego Katolickiego Uniwersytetu we Lwowie'.

W 2015 roku (20-21 października) konferencja AFL6 w Preszowie miała już czterech współorganizatorów: obok Słowacji, Polski i Ukrainy pojawiły się Węgry w osobach trzech prelegentów z Greckokatolickiego Instytutu Teologicznego w Nyíregyházie. Tematem szóstej edycji sympozjum „Ad Fontes Liturgicos” były psalmy: Psalmy jako źródło życia liturgicznego. Re-

5 Por. Reformy liturgii a powrót do źródeł, s. 397.

6 Por. S. Koperek CR, Rok liturgiczny Prospera Guérangera komentarzem wprowadzajacym w liturgię i życie chrześcijańskie, w: Liturgijni komentari jak dżereło liturgiologii, red. V. Rudejko, Lviv 2015, s. 138-150 (Ad Fontes Liturgicos, 5).

7 Por. A. Nowak, Artykuły wstępne w księgach liturgicznych jako źródło wiedzy dla celebransów w metropolii kijowskiej w XVI-XVII w., w: Liturgijni komentari jak dżereło liturgiologii, s. 26-42.

8 W 2011 teksty sympozjum lwowskiego zamieszczono w czasopiśmie „Bohoslovia”.

9 Por. Liturgijni komentari jak dżereło liturgiologii, s. 181. 
prezentowane były tym razem nie tylko katolickie i greckokatolickie, ale i prawosławne ośrodki naukowe (Rumunia, Finlandia). Daleką Finlandię (region Karelia) przedstawiała pani dr Maria Takala-Roszczenko (Uniwersytet Wschodniej Finlandii w Joensuu) z referatem o oryginalnej hymnografii ułożonej na potrzeby greckokatolickiej wersji święta Bożego Ciała ${ }^{10}$. Ogółem na dwudniowej konferencji w Preszowie wystąpiło 17 osób z 7 krajów. Jak ujął to w swoim słowie wstępnym dziekan Wydziału Teologicznego Uniwersytetu Preszowskiego prof. Peter Šturák, międzynarodowy charakter i prestiż sympozjum AFL podniosło także jej finansowe wsparcie przez rzymską Kongregację ds. Kościołów Wschodnich ${ }^{11}$.

Szczególne znaczenie miało siódme sympozjum AFL w 2016 roku (2526 października), gdyż po raz pierwszy odbyło się na Węgrzech, będąc zorganizowane przez Instytut Teologiczny św. Atanazego w Nyíregyházie. Zaangażowani we współpracę międzynarodową w ramach AFL są głównie dwaj wykładowcy tegoż Instytutu, liturgiści István Ivancsó i János Nyirán. Wybrany przez nich temat sympozjum Czas $i$ kalendarz liturgiczny wiązał się z setną rocznicą spotkania biskupów greckokatolickich: Mukaczewa (Zakarpacie), Preszowa i Hajdúdorogu w 1916 roku, które rozpoczęło proces wprowadzania kalendarza gregoriańskiego w tym regionie. Instytut z Krakowa reprezentowało trzech prelegentów. Cenna była obecność prof. Manuela Nin OSB, obecnego egzarchy Egzarchatu Apostolskiego Grecji. Uczestnicy sympozjum zakwaterowani byli w greckokatolickim, narodowym sanktuarium w Máriapócs, co pozwoliło na zapoznanie się z tym ważnym dla całych Węgier miejscem kultu maryjnego.

W oczekiwaniu na pięćdziesięciolecie Instytutu Liturgicznego w Krakowie (według kolejności to krakowski ośrodek miałby organizować kolejną konferencję), dzięki uprzejmości kolegów liturgistów z Ukrainy, sympozjum AFL8 odbyło się po raz trzeci na UKU we Lwowie w 2017 roku (25-26 października) i podejmowało temat $W$ poszukiwaniu źródeł liturgii katedralnej i monastycznej. Konferencja poświęcona była równocześnie

10 Por. M. Takala-Roszczenko, Psalms as Sources of Hymnography for the Ruthenian Feast of the Holy Eucharist, w: Žalmy ako prameň liturgického života, red. V. Bohač, M. Mojzeš, M. Tkač, Prešov 2015, s. 180-197 (Ad Fontes Liturgicos, 6).

11 Por. P. Šturák, Uvodné slovo na otvorení konferencje, w: Žalmy ako prameň liturgického života, s. 8 . 
stuleciu urodzin Juana Mateosa, wybitnego znawcy liturgii bizantyjskiej i ojca współczesnej liturgiki wschodniej, który w swoich badaniach wiele miejsca poświęcił powyższemu tematowi. Na sympozjum obecni byli jego uczniowie o. dr Wasyl Rudejko i prof. Andrew Quinlan z Australii (pracujący obecnie na Ukrainie).

Obecne sympozjum AFL9 w Krakowie zostało związane z obchodami pięćdziesięciolecia krakowskiego Instytutu Liturgicznego, który w sile wieku podjął inicjatywę tych międzynarodowych spotkań liturgistów z krajów Europy Środkowo-Wschodniej i aktywnie w nich uczestniczy. Mamy nadzieję, że sympozja "Ad Fontes Liturgicos” mają przed sobą piękną przyszłość, a dobra współpraca zaprzyjaźnionych już ze sobą ośrodków badań liturgicznych będzie się pogłębiać i przyciągać nowych uczestników dla coraz lepszego wspólnego poznawania i zgłębiania liturgii tradycji wschodniej i zachodniej.

\section{Tematyka dotychczasowych sympozjów „Ad Fontes Liturgicos” (AFL) \\ International Liturgical Symposium "Ad Fontes liturgicos" (AFL). Subject area}

\section{AFL 1, Kraków 21.10.2010}

Powrót do źródet. Metodologia i teologia w badaniach źródeł liturgicznych

A return to the sources. Methodology and theology in the study of liturgical sources

AFL 2, Lwów (Lviv) 26-27.10.2011

Powrót do źródeł. Badanie źródeł liturgii pontyfikalnej

A return to the sources. Studying the sources of the pontifical liturgy

\section{AFL 3, Preszów (Prešov) 25-26.10.2012}

Ruch liturgiczny jako skutek powrotu do źródeł liturgicznych

Liturgical movement as a result of a return to liturgical sources

\section{AFL 4, Kraków 23-24.10.2013}

Reformy liturgii a powrót do źródet

Liturgy reforms and return to the sources 
AFL 5, Lwów (Lviv) 23-24.10.2014

Komentarze liturgiczne jako źródło liturgiologii (nauki o liturgii)

Liturgical comments as a source of liturgiology (the study of liturgies)

AFL 6, Preszów (Prešov) 20-21.10.2015

Psalmy jako źródło życia liturgicznego

Psalms as the source of liturgical life

AFL 7, Nyíregyháza 25-26.10.2016

Czas i kalendarz liturgiczny

Liturgical time and calendar

AFL 8, Lwów (Lviv) 25-26.10.2017

W poszukiwaniach źródeł liturgii typu katedralnego i monastycznego

In the search for the sources of cathedral and monastic liturgies

\section{AFL 9, Kraków 24-25.10.2018}

W stużbie tradycji i odnowy liturgicznej (50 lat Instytutu Liturgicznego w Krakowie)

In service to tradition and liturgical renewal (50 years of the Liturgical Institute in Krakow)

\section{Summary}

International Liturgical Symposium "Ad Fontes Liturgicos". A short story of the new initiative of the Liturgical Institute in Krakow

A new initiative of the Liturgical Institute is the international liturgical symposia called "Ad Fontes Liturgicos". The initiative of these annual meetings of liturgists was born in 2010 in cooperation of scientific and research units from three neighboring countries: Poland, Ukraine and Slovakia. In addition to the UPJPII Liturgical Institute, symposia are organized by the Ukrainian Catholic University in Lviv (the Department of Liturgical Sciences) and the Greek Catholic Faculty of Theology of the University in Prešov. In 2015, the Theological Institute of Saint Athanasius in Nyíregyháza from Hungary joined this group of co-organizers of the sympo- 
sium. Symposia "Ad Fontes Liturgicos" are held regularly every year at the end of October, and their hosts are alternating universities from the above-mentioned countries of Central and Eastern Europe. After the symposiums, with the efforts of the individual host centers, the texts of the lectures are published in volumes which form the international series Ad Fontes Liturgicos. So far, six volumes of the series have been published in print (the volume seventh is in print, and eighth in preparation). The idea of the "Ad Fontes Liturgicos" (AFL) symposia is to enable the meeting and discussion of specialists from different countries and belonging to various liturgical traditions (Latin and Byzantine) studying the sources of liturgy in order to present the results of their research, discuss and exchange of research and didactic experiences. 